\title{
PATHOLOGICAL STUDIES ON BCG AND HYPERICIN MEDIATED PHOTODYNAMIC THERAPY (PDT) IN TUMOR TREATMENT IN MICE
}

\author{
AL KLAMAWEY, NAGLAA M. ${ }^{1}$, M. B. EL-BEGAWY ${ }^{2}$, GEHAN G. SHEHAB ${ }^{1}$ \\ AND A. A. SHALABY ${ }^{2}$ \\ 1 Animal Health Research Institute, ARC, Ministry of Agriculture, Dokki - Giza \\ 2 Faculty of Veterinary Medicine, Beni - Suef University
}

(Manuscript received 19 April 2011)

\begin{abstract}
The purpose of the current study is to evaluate the effectiveness of Hypericin Photodynamic therapy (PDT) alone or associated with BCG immunization as an oncotherapy in Swiss mice. For this purpose, 90 mature male swiss mice were chosen and equally divided into 5 comparable groups. The first, was a negative control group, the second was hypericin contol group and the third was tumor control group. The forth and fifth groups were the treated groups with Hypericin-PDT and BCG/ Hypericin - PDT, respectively. They were subjected to the treating regimen as follows: a dose of $5 \mathrm{mg} / \mathrm{kg}$ body weight of an aqueous ethanolic Hypericin solution was injected by both intra-peritoneal (i.p.) and intratumoral (i.t.) injections, followed 2 hours later by exposure to non-coherent light $(590 \mathrm{~nm})$ for 5 minutes in each session. Mice received 5 sessions / week for 6 weeks. Both treatments resulted in pronounced degeneration and necrosis of the neoplastic cells with replacement of tumor masses by fibrous connective tissue. The curative rate was enhanced when Hypericin-PDT was accompanied by BCG as an immuno-stimulating agent. From the pathological pictures, it can be concluded that Hypericin-PDT is an effective treatment for superficial neoplasms. BCG administration, as a non-specific immuno-stimulant, enhances the therapeutic effect of Hypericin -PDT.
\end{abstract}

\section{INTRODUCTION}

Cancer is still a disease that causes a major threatening for human and animal life, in addition to the cost effectiveness in its treatment (Epstein, 1990).

There are various therapeutical approaches for treatment of tumors, the selection of certain approach depends mainly on the tumor location.

Photodynamic therapy (PDT) might be the treatment of choice for superificial tumors, and in other situations, it can be used as an adjuvant or palliative treatment (Lilge et. al., 1997 ).

Photodynamic therapy involves the relatively selective uptake of a photosensitizig drug and a subsequent irradiation with light of a suitable wave length corresponding to the peaks absorption of the drug (Henderson and Dougherty, 1992). 
The useful photosensitizer should have a narrow absorption band, selective accumulation in tumor tissues, fast clearance from the normal tissues and low toxicity (Bonnett, 1994). Hypericin, is considered as a second generation of photosensitizers; it showed an increased photodynamic efficiency in the treatment of tumors and reduced phototoxicity (Ochsner, 1997).

The aim of the present study is to evaluate the effectiveness of hypericin photodynamic therapy (PDT) alone or associated with BCG immunization as an oncotherapy in mice.

\section{MATERIALS AND METHODS}

\section{Experimental animals}

This study was conducted on 90 mature male swiss mice with an average weight of $25-30 \mathrm{~g}$. They were left two weeks for acclimatization, then, they were equally divided into 5 comparable groups. Throughout the experimental period, they were kept under constant environmental conditions and offered food and water adlibitum.

\section{Tumor transplantation}

Ehrlichia tumor line obtained from National Cancer Institute, Cairo, Egypt with approximately $5 \times 10^{5}$ tumor cells in $0.2 \mathrm{ml}$ serum free medium were inoculated subcutaneously into the dorsal aspect of the upper back of 54/90 mice. Tumors were used for experimentation when they reached a surface diameter of $3-7 \mathrm{~mm}$ measured by vernier caliper. Tumor volume was calculated by the formula (Chung et. al., 2000). $V=p / 6(L \times W \times H)$ whereas:

\section{Preparation of Hypericin (Hyp)}

Hypericum perforatum extract in a powder form was purchased from Seekum, Pharmaceutical Co., Al-Sharkeya Gov. Each gram powder of Hypericum perforatum extract contained $275 \mathrm{mg}$ Hypericin. The extract was dissolved in $70 \%$ aqueous ethanol to prepare a stock solution containing $192 \mathrm{mg}$ hypericin $/ \mathrm{ml}$ ethanol, and stored at $-20{ }^{\circ} \mathrm{C}$ in dark place. Hypericin dose was equivalent to $5 \mathrm{mg} / \mathrm{Kg}$ body weight (or 125ug hypericin / mice) (VanderWerf et. al., 1996).

\section{Bacille Camellete - Guerin ( BCG ) vaccine}

Lyophilized BCG vaccine in vials each containing $0.5 \mathrm{mg}$ was purchased from Public Organization of Medical Products, Ministry of Health, Agoza, Giza, Egypt. Each BCG vial was diluted in BCG vaccine solvent (according to the labeled information and enclosed pamphlet). 


\section{Light source and dosimetry ( Non-coherent light )}

Irradiation was performed using non-coherent light source using tungsten lamp with central wavelength of $590 \mathrm{~nm}$ and a delivery system of fiberoptic cable made by Photon Co., Egypt.

The Experimental design

\section{Negative control group}

Eighteen/ninety mice did not receive any light or chemical treatment.

\section{Hypericin control group}

Eighteen/ ninety mice were injected subcutaneously (sc) into the dorsal aspect of the upper back and intraperitoneal (ip) by hypericin solution with a dose rate of $5 \mathrm{mg} / \mathrm{kg}$ body weight in each route. Injections were applied 5 times / week for 6 successive weeks.

\section{Tumor control group}

Eighteen/ ninety mice were subjected to subcutaneous inoculation of Ehrlichia cell line as previously described and left without treatment along the experimental period.

\section{Hypericin assisted photodynamic therapy group (PDT Group)}

Eighteen/ ninety tumor -bearing mice were subjected to PDT protocol. As the tumor surface area reached $3-7 \mathrm{~mm}$ in diameter, tumor sites were depilated using hair-removal cream, and Hypericin was administrated by i.p. and intratumoral (i.t.) routes, at a dose rate of $5 \mathrm{mg} / \mathrm{Kg}$ by both routes. Two hours after administration, animals were anesthetized by xylazine $\mathrm{HCl}$ at $13 \mathrm{mg} / \mathrm{kg}$, together with Ketamine $\mathrm{HCl}$ at $87 \mathrm{mg} / \mathrm{kg}$ by intramuscular route, and then, the tumors were irradiated with the light source. The light density was used at $120 \mathrm{~J} / \mathrm{cm}^{2}$ for $5 \mathrm{~min} /$ session (Blank et. al., 2001). Mice received 5 sessions / week for 6 weeks.

\section{BCG/hypericin PDT-treated group}

Eighteen/ ninety tumor-bearing mice received BCG at a dose rate of 25ug / mice, at the same time of tumor cell line inoculation. When the tumor surface area reached $3-7 \mathrm{~mm}$ in diameter, animals were subjected to the previously illustrated hypericin/ PDT treated group.

\section{Pathological examination}

Three mice from each control and treated groups were examined clinically and were sacrificed weekly for 6 weeks. Careful necropsy and macroscopical examination of the sacrificed mice were done. Skin tissue specimens from control and treated groups were collected and fixed in $10 \%$ neutral formalin, dehydrated in ethyl alcohol, cleared in xylene and embedded in paraffin. Sections of 4-5 microns were obtained and stained with $\mathrm{H} \& \mathrm{E}$ for routine histopatholoigcal examination. Alizarin red was used 
to demonstrate calcium salts, and Masson's Trichrome was used for fibrous connective tissue detection (Bancroft and Stevens, 1996).

\section{RESULTS}

Gross examination of hypericin Control mice revealed that the picture of injected area became hard in texture with loss of hair at the $4^{\text {th }}$ week, while, there appeared severe hardness at the site of hypericin injection with brown colour in association with easily detached hair at the end of the $6^{\text {th }}$ week.

The gross examination of tumor control group revealed slowly grown tumor masses with no clear borders till the $3^{\text {rd }}$ week. Three weeks later, the tumor showed fast growth rate that gave rise to voluminous hard and ulcerate tumor masses. The most noticeable appearance was the tendency of the tumor to grow in a diffuse manner throughout the experimental period (Figs. 1 and 2).

Gross examination of PDT-group showed progressive reduction in tumor size. At the $3^{\text {rd }}$ week, some tumors had cavitations on cut sections. These cavities contained liquefied necrotic debris. At the end of the $5^{\text {th }}$ and $6^{\text {th }}$ weeks, there was marked regression in the tumor masses which were replaced in large areas by scar tissue (Figs. 1 and 2).

Gross examination of BCG -PDT regimen exhibited progressive retardation in tumor growth with circumscribed pattern of growth and clear borders. At the end of the $6^{\text {th }}$ week, there was marked improvement in the curing process than in PDT-group indicated by replacement of most tumor masses by mature scar tissue (Figs.1\&2).

Microscopic examination of hypericin control group revealed appearance of heavy inflammatory cells infiltration, mainly neutrophils, lymphocytes and macrophages laden with yellow-brown pigment granules, and by the extension of the experimental period, there was marked increase in the number of macrophages. At the end of the $6^{\text {th }}$ week, there was marked hyperkeratosis with thickening in the epidermal layer in some areas. The upper dermal layer had proliferated microvasculature with small areas of haemorrhage, while, the deeper dermal layer showed multiple necrotic areas and aggregations of lymphocytes and macrophages (Fig. 3).

Microscopic examination of tumor control group revealed highly condensed viable tumor cells varied in shape and size. Scattered necrotic foci within viable tumor cells were also seen. By advancement of the experiment, the anaplastic changes were more distinguishable in association with high mitotic activity (Fig.4). The functional blood vessels showed congestion and haemorrhages. 
Microscopic picture of PDT-treated group : at the early stage, the tumor masses were composed of highly condensed viable tumor cells. At the second and third weeks, tumor cells showed swollen appearance and / or disrupted membrane. Some swollen tumor cells had autophagic vacuoles containing debris in the cytoplasm with no nuclear changes (Fig.5). Multiple necrotic foci were detected and became more pronounced by the time. Most of the necrotic areas were separated from the surroundings by a reaction in the form of fibrous connective tissue infiltrated by inflammatory cells associated with vascular reaction manifested by newly formed vasculature with congestion and destruction (Fig.6). At the $4^{\text {th }}$ week, the tumor masses were noticeably reduced in size and composed of more loose and less viable tumor cells admixed with adipose and fine strands of fibrous connective tissue. The central areas of tumor showed necrosis and even calcification (Fig.7). At the $5^{\text {th }}$ and $6^{\text {th }}$ weeks post - treatment, the viable tumor cells showed less mitotic activity with marked arrest in tumor cells proliferation. Large areas of tumor masses showed granulation tissue formation of fibrous connective tissue within which, small blood vessels were present in association with macrophages infiltration (Fig. 8).

BCG- PDT group : at the early stage of treatment, significant changes were reported in the form of pronounced inflammatory reaction at the periphery of the tumor masses associated with large numbers of multinucleated giant cells (Fig. 9). Moderate reduction in the number of viable tumor cells in comparison with tumor control group was seen. The picture of cell necrosis increased, especially in the area with damaged blood vessels. Tumor masses continued to regress with less density of viable tumor cells compared with PDT group (Fig. 10). The degenerated tumor cells showed the pathological criteria of necrosis, programmed cell death characterized by cell shrinkage, nuclear fragmentation and chromatin condensation, and even calcification (Fig. 11). Large number of tumor giant cells and macrophages containing phagosomes were detected infiltrating the newly formed fibrous connective tissue. At the $5^{\text {th }}$ and $6^{\text {th }}$ weeks, there was marked arrest of tumor cell proliferation with less significant number of viable tumor cells. Most of the tumor masses were substituted by adipose tissue and mature granulation tissue (Fig. 12).

\section{DISCUSSION}

Photodynamic therapy (PDT) is an experimental modality for treatment of tumor based on the presence of a photosensitizing agent (photosensitizer) which accumulates in the neoplastic tissue and could be activated by certain light source which matches the absorption spectrum of the photosensitizer. The subsequent 
liberated free radicals and singlet oxygen, damage the vascular endothelium and / or the cell membrane with an end result of tumor cell necrosis (Ochsner, 1997).

In the current study, hypericin (Hyp) was used as a photosensitizing agent. The successful incorporation of hypericin into the cells was clarified microscopically in the hypericin control group by the presence of the hypericin pigment granules into the macrophages as a yellow-brown pigment.

Hypericin is known to be a lipophilic molecule (Takahashi et. al., 1989) that can be incorporated in phospholipid bilayers of the cell plasma membrane (Tang et. al., 1990) with subsequent more affinity to tumor cells (Chung et. al., 1994).

Because PDT is performed when the plasma drug level is high, it is likely that vascular damage results in the leakage of hypericin out the entire edematous area with more powerful cytotoxic effect through high yield of singlet oxygen. The i.t. route of hypericin injection was used to provide the real advantages for both of tumor localization and decreased normal tissue phototoxicity compared with conventional systemic dye administration. On the other hand companied i.p. route was used to maximum hypericin concentration in the skin (Uzdensky et. al., 2002).

Selection of the wavelength $(590 \mathrm{~nm})$ was depending on the aromatic ring structure of this dianthraquinone (hypericin) which resulted in strong absorption peaks at 550 and $590 \mathrm{~nm}$ with high power for tissue penetration at $590 \mathrm{~nm}$, and subsequently, high production of ROS within the cell, which ultimately resulted in irreversible damage of vital cell components (VanderWerf et. al., 1996).

In the current study the photoactivated tumor masses showed gradual regression in the tumor size of both PDT and BCG/PDT groups, in comparison with the tumor control group.

The ability of photoactivated hypericin to induce necrosis had been related to its ability to induce degeneration of the viable tumor cells.

The most predominant type of cellular degeneration in the present study was the necrosis in the form of swollen appearance of the tumor cells with membrane disruption. Moreover, there were different stages of necrosis beginning from individual cell necrosis till massive necrosis with end step of calcium deposition. The recorded necrosis could be attributed to the secondary vascular shutdown. Tissue ischemia as a result of the decreased blood perfusion starves tumor cells till death. Inactivation of the blood vessels in the tumor center of the treated groups occurred earlier than in the tumor periphery and surrounding tissue (Hamilton et. al., 1996).

Meanwhile, the necrotic effect of photoactivated hypericin is related to the release of the mitochondrial cytochrome $c$ into the cytosol which is followed by procaspase-3 activation, and subsequently, induction of necrotic machinery. During 
photodynamic activation of hypericin, light is absorbed and produced an excited triplet state before transfer of energy to ground-state oxygen, creating singlet oxygen as the primary oxidant. The highly reactive singlet oxygen is toxic to the mitochondria, where it inhibits succinoxidase causing cell death (VanderWerf et. al., 1996, Chung et. al., 1994 and Uzdensky et. al., 2002).

Concerning the BCG/PDT group, there was detectable variation in the mode of tumor growth, as tumors tend to be more circumscribed in comparison with the diffuse manner of growth which was pronounced in PDT group and tumor control group. Furthermore, BCG/PDT group exhibited a perfect response detected by the macroscopic appearance which showed marked regression in tumor masses with enhancement of the curative rate at the end of the experimental period. At the early stages of treatment, there was marked increase in the number of macrophages which helped in removal of dead and necrotic tissue. Continuous removal of necrotic tissue improved the replacement of tumor mass by fibrous connective tissue at the end of the experimental period.

From the current study, it could be concluded that, Hypericin-PDT could be considered as a treatment of choice for superficial neoplasms. Immune-stimulation with BCG enhances the response of the tumor to the PDT through removal of necrotic debris. 
Figs. 1. The gross appearance of tumor masses in the tumor control group and treated groups of mice during the first three weeks.

\section{Fig. (4-a):}

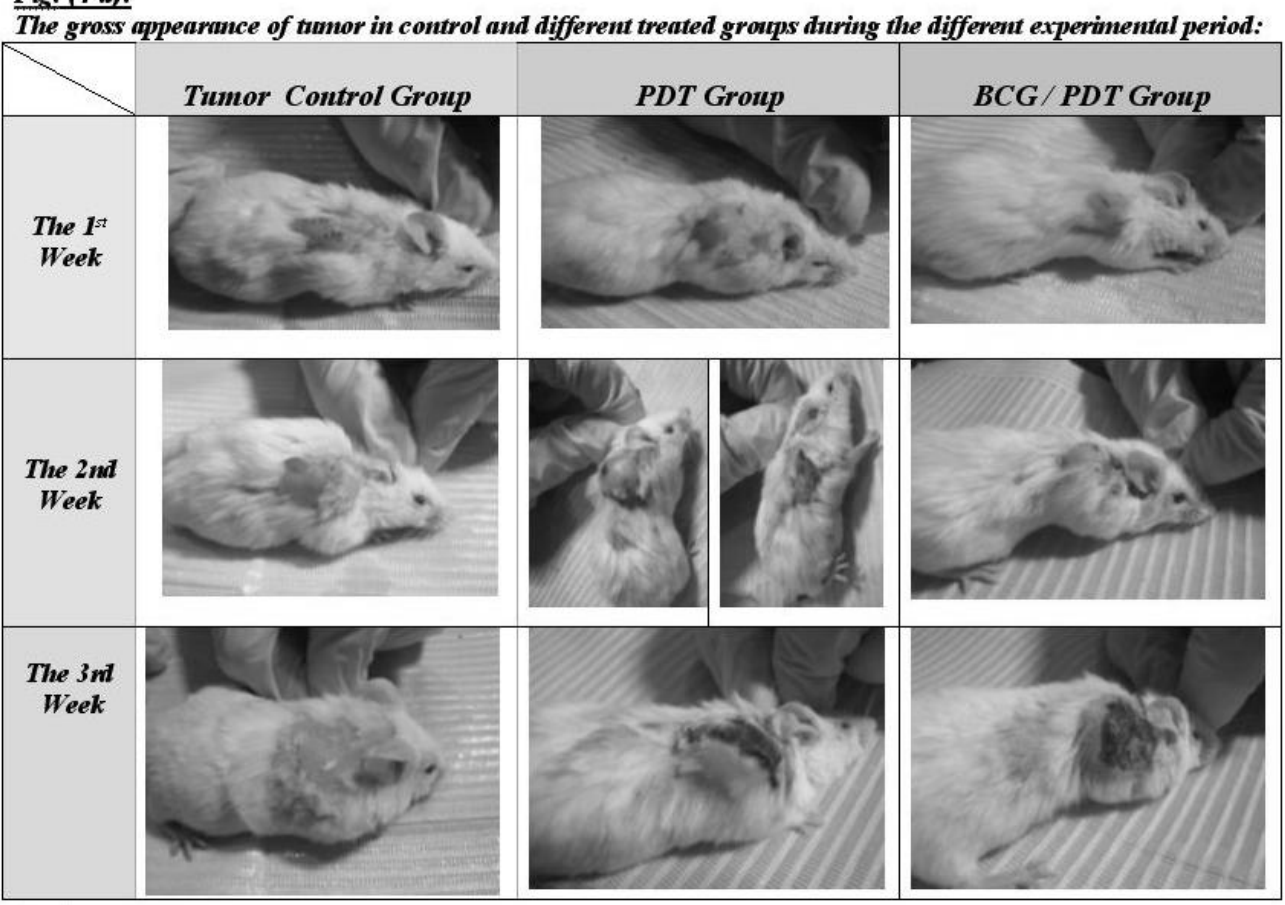

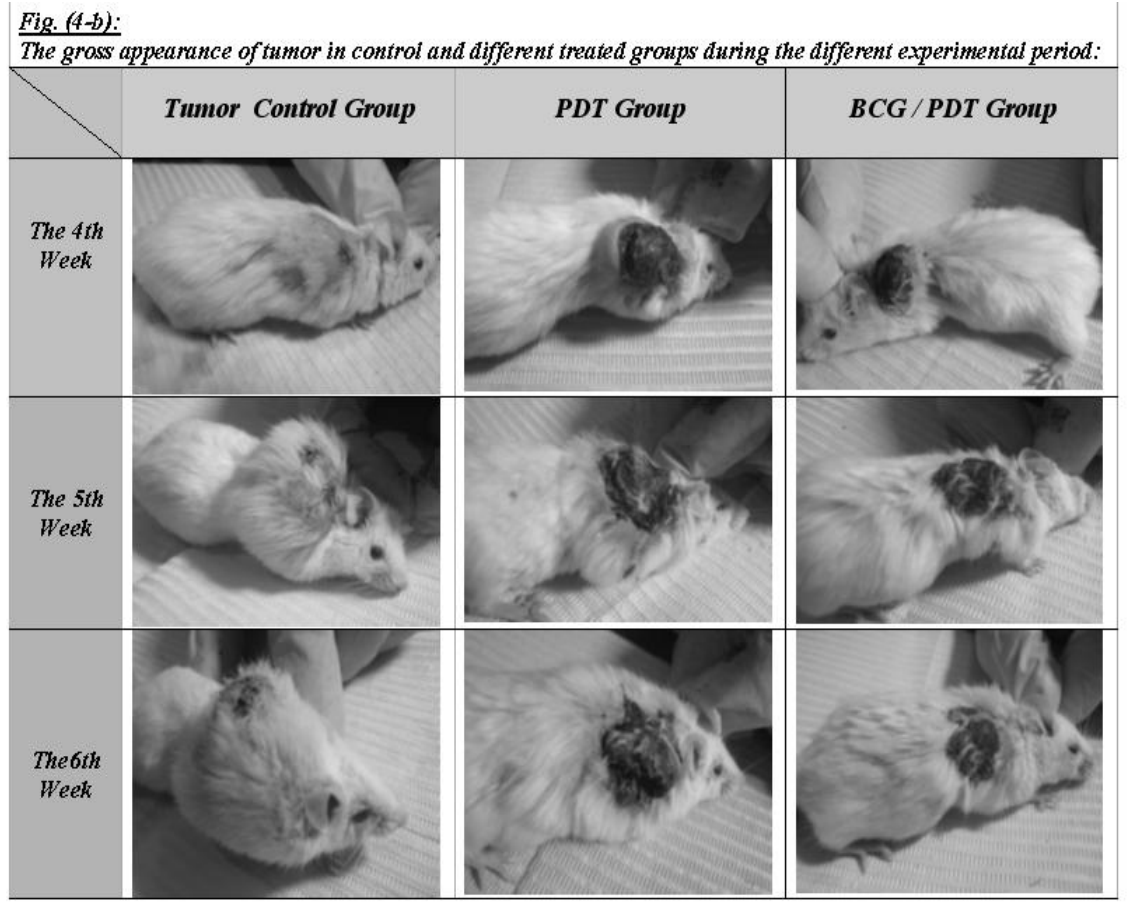

Fig. 2. The gross appearance of tumor masses in the tumor control group and treated groups of mice during the last three weeks. 


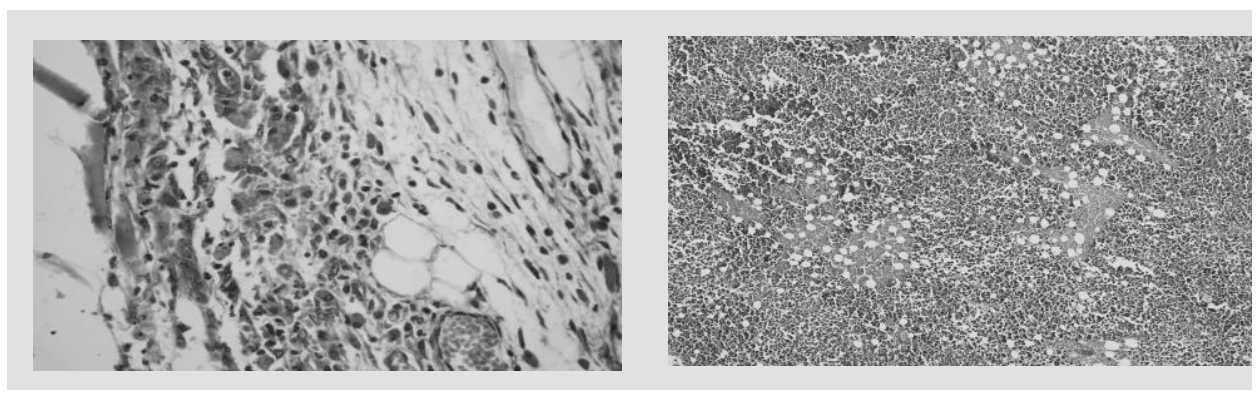

Fig. 3. Hypericin control group of mice at the $6^{\text {th }}$ week showing congestion of the subepidermal vasculature (asterisks) with inflammatory cells infiltration. The macrophages were laden by yellowish -brown pigment. H\&E X 200

Fig. 4. Tumor control group of mice showing highly condensed viable tumor cells under an intact epithelial surface with multiple focal areas of necrosis. H\&E X 100.

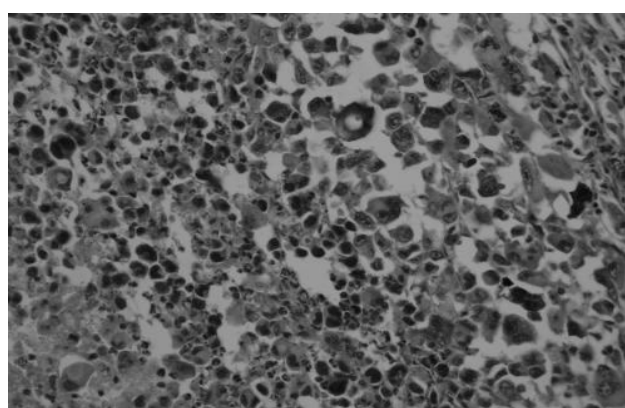

Fig. 5. PDT-group of mice at the 2nd week revealing evidences of cytoplasmic swollen accompanied by loss of cell membrane integrity with multiple cytoplasmic vacuolization. $\mathrm{H} \& \mathrm{E} X$ 400.

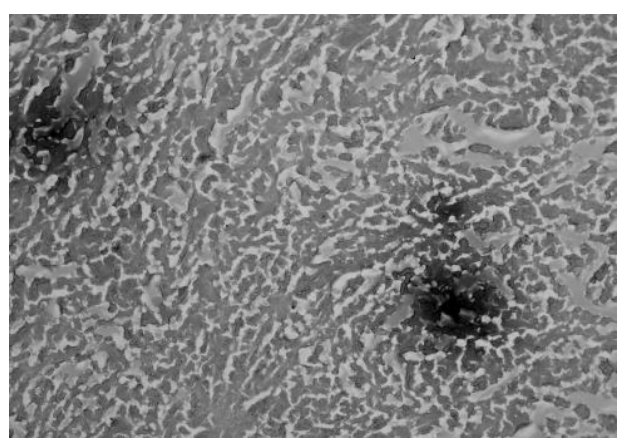

Fig. 7. PDT-group of mice at the 4th week showing reduction of the tumor mass which showed central calcification and surrounded by fibrous connective tissues. Alizarin red X100.

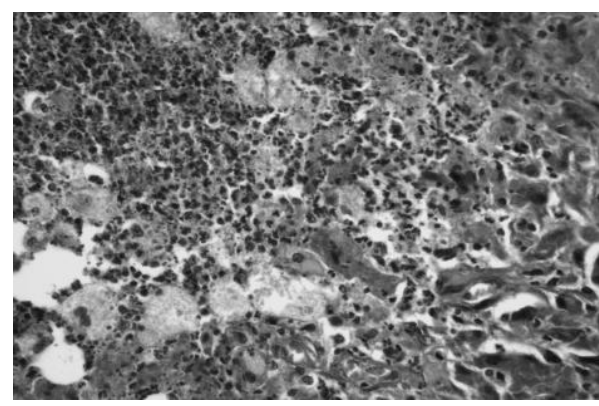

Fig. 6. PDT-group of mice at the 3rd week illustrating proliferation of FCT with neutrophils infiltration associated with congestion and destruction of the newly formed vasculature. $H \& E 200$.

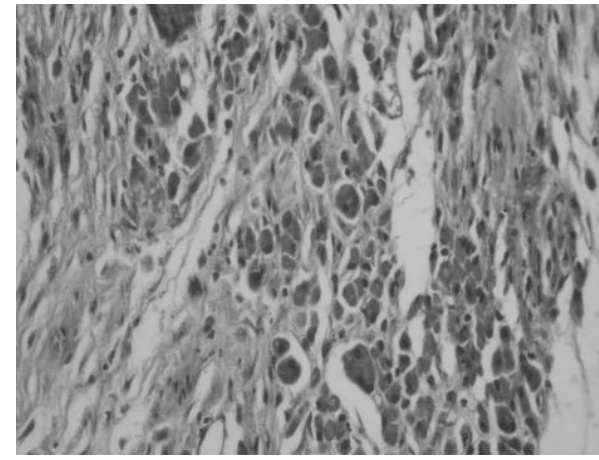

Fig. 8. PDT-group of mice at the $6^{\text {th }}$ week showing substitution of large area of tumor mass by granulation tissue formation.

H\&E X 200 . 


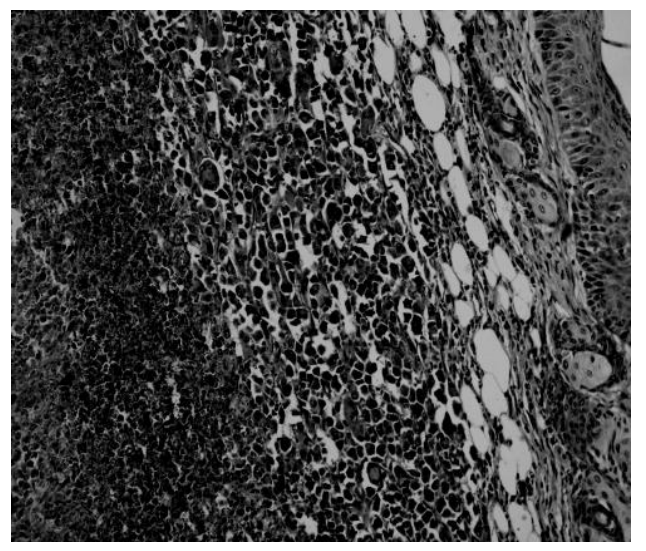

Fig. 9. BCG/PDT group of mice at the 1st week showing marked skin reaction between the healthy tissue and the necrotic tumor mass in the form of inflammatory cells infiltration in addition to multinucleated giant cells. H\&E X 200

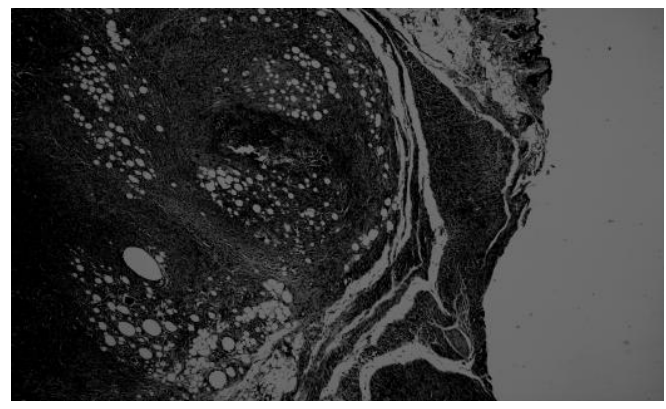

Fig. 11. BCG/PDT-group of mice at the $4^{\text {th }}$ week showing calcium salts deposition in the center of necrosed tumor mass. $\mathrm{H} \& \mathrm{EX}$ 200.

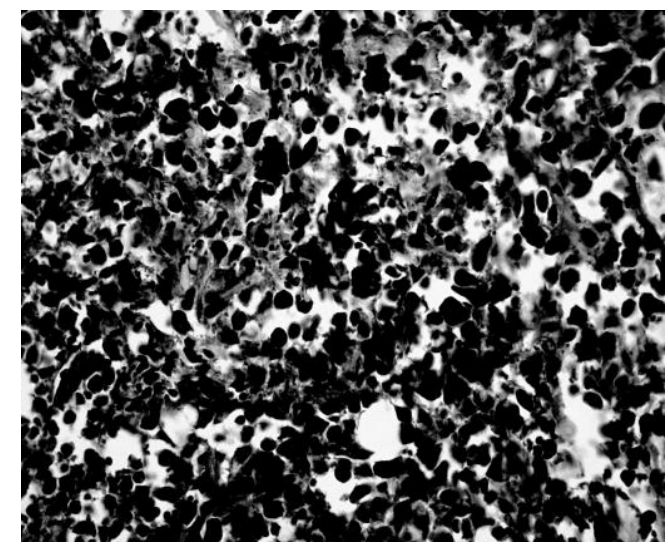

Fig. 10. BCG/PDT group of mice at the 3rd week showing less density of viable tumor cells with less mitotic activity. H\&E X 400

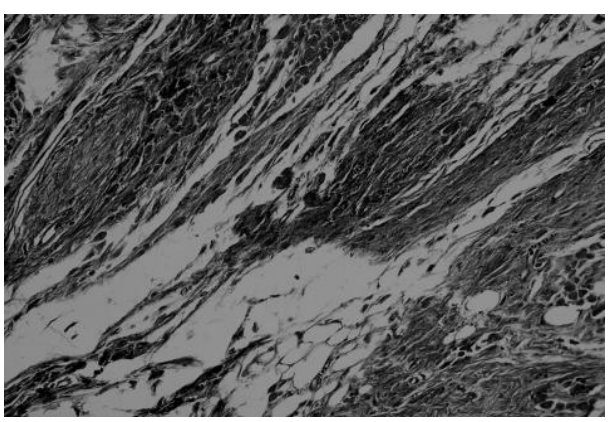

Fig. 12. BCG/PDT-group of mice at the 6th week showing marked substitution of tumor mass by granulation tissue, macrophages, well organized FCT and even adipose tissue. Masson's trichrome X400. 


\section{REFERENCES}

1. Bancroft, J. D. and A. Stevens. 1996. Theory and Practice of Histopathological Technique. $4^{\text {th }}$ Ed., Churchill, Livingston, Edinburgh, London, Melbourne and New York.

2. Blank, M.G., G. Kostenich, S. Lavie, Y. Kimel, S. Keisari and A. Orenstein. 2002. Wavelength - dependent properties of photodynamic therapy using hypericin in vitro and in an animal model. Photochem. photobiol, 76 (3) : 335-340.

3. Blank, M. M., S. Mandel, Y. Hazan, I. Keisari and G. Lavie. 2001. Anti - cancer activities of hypericin in the dark. Photochem. Photobiol., 74 (2) : $120-125$.

4. Bonnett, R. 1994. Photosensitizers for the photodynamic therapy of tumors. Pro. Sco. Photo-Opt. Instrum. Eng., 2078 : 74-90.

5. Chung, P. S., C. K. Rhee, K. H. Kim, W. J. Paek, M. B. Chung, M. B. Paiva, A. A. Eshraghi, D. J. Castro and R. E. Saxton. 2000. Intratumoral hypericin and KTP laser therapy for transplanted squamous cell carcinoma. The Laryngoscope, 110 : 1312-1316.

6. Chung, P. S., R. E. Saxton, M. B. Paiva, C. K. Rhee, J. Soudant, A. Mathey, C. Foote and D. J. Castro. 1994. Hypericin uptake in rabbits and nude mice transplanted with human squamous cell carcinoma: study of a new sensitizer for laser phototherapy. Laryngoscope, $104: 1471-1476$.

7. Epstein, J. M. 1990. Phototherapy and photo chemotherapy. N. Engl. J. Med., 32 : 1149-1151.

8. Hamilton, H. B., R. Hinton, E. R. Law, R. Gopalakrishna, Y. Z. Su, Z. H. Chen, M. H. Weiss and W. T. Couldwell. 1996. Inhibition of cellular growth and induction of apoptosis in pituitary adenoma cell lines by the protein kinase $\mathrm{C}$ inhibitor hypericin: potential therapeutic application. J. Neurosurg., 85 : 329-334.

9. Henderson, B. W. and T. J. Dougherty. 1992. How does photodynamic therapy work? Photochem. Photobiol., 55 : 145-157.

10. Lilge, L. D., J. Pang, J. Jonkman, and B. C. Wilson. 1997. Feasibility study of PDT light sources based on lasing action in strongly scattering media. In : Optical Methods for Tumor Treatment and Detection, Mechanisms and Techniques in Photodynamic Therapy. $6^{\text {th }}$ Ed., Dougherty, T.J. : 130-135.

11. Ochsner, M. 1997. New trends in photobiology (Invited review): Photophysical and photobiological processes in the photodynamic therapy of tumors. J. Photochem. Photobiol. B. Biology, 39 : 1-18. 
12. Takahashi, I., S. Nakanishi and E. Kobayashi. 1989. Hypericin and pseuduhypericin specifically inhibit protein kinase C: possible relation to their antiretroviral activity. Biochem. Biophys. Res. Commun., 165 (3) : 1207-1212.

13. Tang, J., J. M. Colacino, S. H. Larsen and W. Pitzer. 1990. Virucidal activity of hypericin against enveloped and non - enveloped DNA and RNA viruses. Antiviral Res., 13 (6) : 313-326.

14. Uzdensky, A.B., V. Iani, L. W. Ma and J. Moan. 2002. Photobleaching of hypericin bound to human serum albumin , cultured adenocarcinoma cells and nude mice skin. Photochem. Photobiol., 76 (3) : 320-328.

15. VanderWerf, Q. M., R. E. Saxton, A. Chang, D. Horton, M. B. Paiva, J. Anderson, C. Foote, J. Soudant, A. Mathey and D. J. Castro. 1996. Hypericin : A new laser phototargeting agent for human cancer cells. Laryngoscope, 116, 479-483. 


\section{دراسات باثولوجية على علاج الأورام فى الجرذان بواسطة الهيبرسين}

\section{المستحث ضوئيا}

نجلاء محمد القلماوى' ، محمود بدوى البيجاوى' ، جيهان جميل شهاب' ، عادل عباس شلبى'

$$
1 \text { كلبة الطب البيطرى - جامعة بنسى سويف - مركز البحوث الزرراعبة - وزارة الزراعة- الدقى-جيزة }
$$

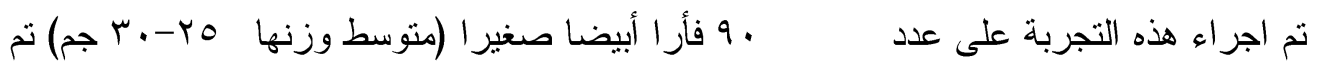
تقسيمها إلى خمس مجموعات متساوية كل منها تحتوى على م أفأر ا. المجموعة الأولى إستخدمت كمجموعة ضابطة سالبة. المجموعة الثانية إستخدمت كمجمو عة ضابطة لمادة الهييرسين وتم حقنها بجرعة ه جم/كجم فى جرعتين متساويتين بكل من الحقن البريتونى و الحقن تحت الجلد مرات مرات

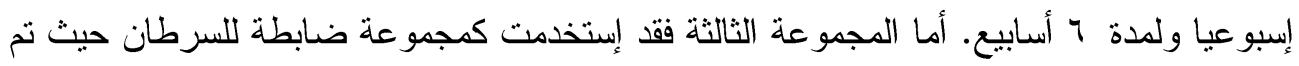

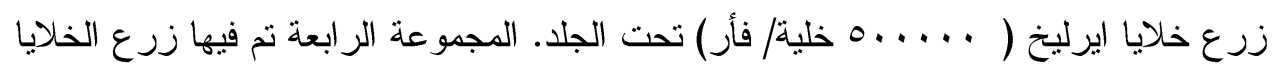
السرطانية (وبعد أسبوعين من نمو السرطان) تم تطبيق العلاج الضوئى كما يلى : تم حقن الهيبرسين

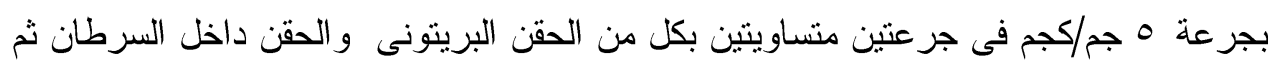

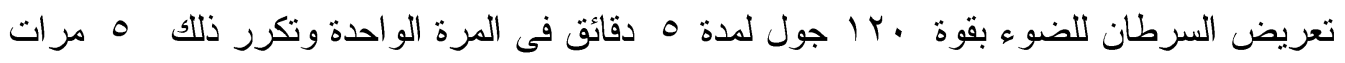
إسبو عيا لمدة 7 أسابيع. المجموعة الخامسة نم علاجها مثل المجموعة الر ابعة بالإضافة الى تلى تحصينها

$$
\text { بـلقاح بى • سى . جى متز امنا مع استزر اع الخلايا السرطانية. }
$$

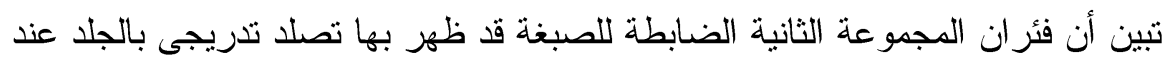

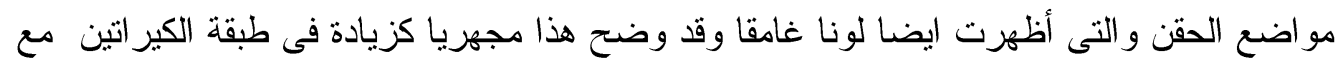
وجود خلايا ملتهمة محملة بصبغة بنية تميل للون الأصفر .

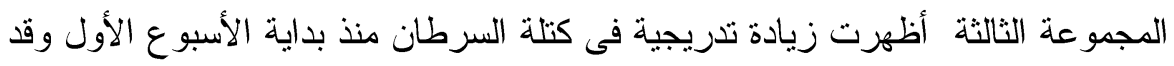
أصبح النمو السرطانى نشطا عند الأسبوعين الخامس و السادس.

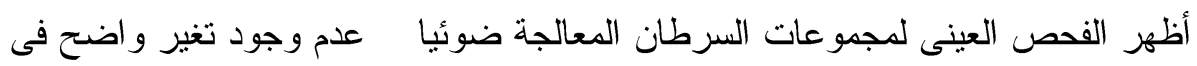

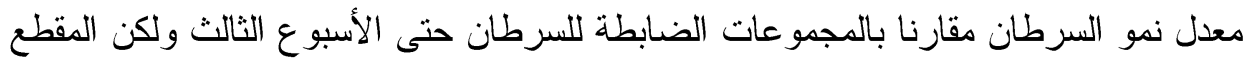
العرضى أظهر تجويفات مملو عه بمادة متتكرزة وخلايا منتحرة مع وجود عدد كبير من الخلايا

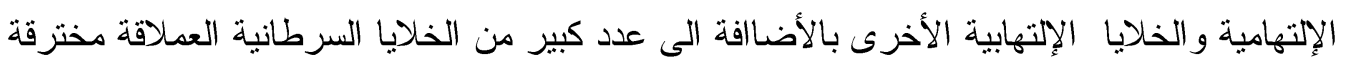
الكتلة السرطانية.

بالتقدم فى التجربة ظهر ضمور فى حجم الكتل السرطانية مع تكوين أنسجة ندبية والتى كانت و اضحة و سريعة في المجمو عة الخامسة مقارنة بالمجمو عة الر ابعة .

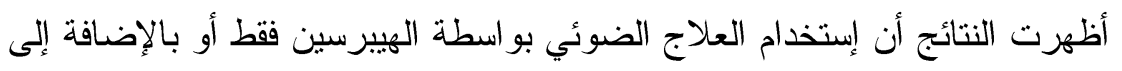

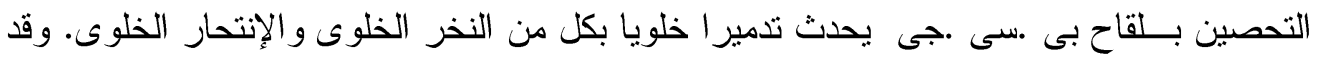

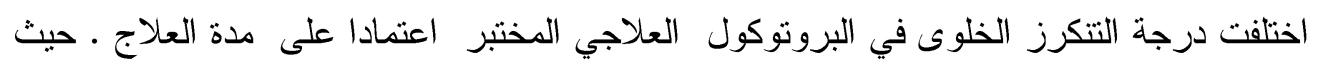


أنه إتباعا لهذا البرتوكول العلاجي كان هنالك علامات إنتحار خلوى واضح ة وذلك عند المراحل

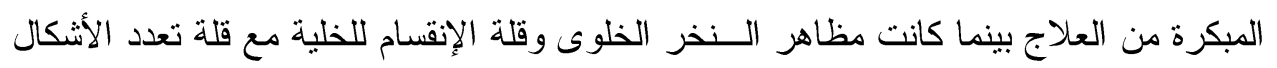
ظهرت مع طول فترة العلاج حيث تم إحلال الكتلة السرطانية المرتدة بنسيج متحبب مكون من نسيج ليفي ضام و شعير ات دموية متكاثرة. أوصت الدر اسة الحالية بإستخدام العلاج الضوئى بو اسطة الهيبرسين مع التحصين بلقاح

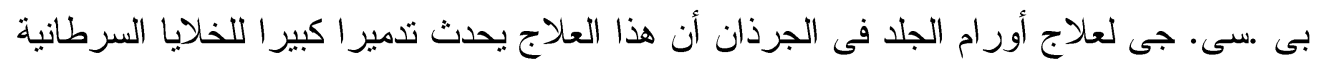
بالاضافة الى إحلال الكتلة السرطانية المتتكرزة بنسيج ليفى ضام وشعير ات دمونية لدئ متكاثرة ( أنسجة 